\title{
RADIOCARBON AGES OF ANNUAL RINGS FROM JAPANESE WOOD: EVIDENT AGE OFFSET BASED ON INTCAL09
}

\begin{abstract}
Toshio Nakamura ${ }^{1,2} \bullet$ Kimiaki Masuda $^{3} \cdot$ Fusa Miyake $^{3} \cdot$ Kentaro Nagaya $^{3} \cdot$ Takahiro Yoshimitsu $^{4}$
ABSTRACT. To investigate the radiocarbon concentration of atmospheric $\mathrm{CO}_{2}$ over the past few millennia in Japan, we measured the ${ }^{14} \mathrm{C}$ age of annual rings from 3 Japanese trees with calendar dates ranging from $\sim 2000 \mathrm{yr}$ old to present, and we compared the tree-ring ${ }^{14} \mathrm{C}$ age with the corresponding ${ }^{14} \mathrm{C}$ age from IntCal09. In some instances, the ${ }^{14} \mathrm{C}$ ages of the annual rings of Japanese trees are not consistent with the IntCal09 data sets. Often, the ${ }^{14} \mathrm{C}$ ages of tree rings are older than those from IntCa109, but younger than those from the SHCal04 data sets. The average shifts in the Nagoya ${ }^{14} \mathrm{C}$ age from IntCa109 data sets and $1 \sigma$ errors were determined to be $+26 \pm 36,+24 \pm 30,+16 \pm 22,+5 \pm 21$, and $+14 \pm 22{ }^{14} \mathrm{C}$ yr for the intervals $\mathrm{AD} 72-$ $382,589-1072,1413-1615,1617-1739$, and 1790-1860, respectively. The Japanese Archipelago is situated near the boundary of the Intertropical Convergence Zone in summer, and the ${ }^{14} \mathrm{C}$ concentration of atmospheric $\mathrm{CO}_{2}$ over Japan can be influenced by air masses of the Southern Hemisphere with lower ${ }^{14} \mathrm{C}$ concentrations during periods of higher solar activity and heightened East Asian summer monsoons. Our results suggest that the Japanese Archipelago is located in a critical zone where it is difficult to calibrate the ${ }^{14} \mathrm{C}$ age of tree-ring samples using existing calibration data sets. It should be noted that calibration of the ${ }^{14} \mathrm{C}$ dates of Japanese samples with IntCal09 may induce additional systematic shifts of calibrated ages toward older ages by about $30 \mathrm{yr}$ compared with the sample optimum calendar ages.
\end{abstract}

\section{INTRODUCTION}

Radiocarbon dating is widely applied to archaeological materials and cultural assets that are sometimes closely related with historical events. In particular, ${ }^{14} \mathrm{C}$ dating is used to determine whether sample materials are actually related to historical events. If the materials turn out to be imitations with no relation to historical events, further scientific investigations on them would be pointless. Thus, highly accurate dating of samples is required to distinguish genuine artifacts from the fake ones. The accuracy of ${ }^{14} \mathrm{C}$ dating results is determined largely by the appropriateness of sample preparation and measurements of ${ }^{14} \mathrm{C}$ abundance of the prepared targets. However, it is also related to the procedures used to obtain reliable calendar ages when calibrating conventional ${ }^{14} \mathrm{C}$ ages. For ${ }^{14} \mathrm{C}$ age calibration, IntCal09 (Reimer et al. 2009) data sets are normally used for terrestrial samples whose carbonaceous fractions were synthesized from atmospheric $\mathrm{CO}_{2}$ in the Northern Hemisphere, while SHCal04 (McCormac et al. 2004) data sets are used for those from the Southern Hemisphere.

The accuracy of a calendar age obtained by calibration with the IntCal09 data sets is, however, sometimes questioned because of the possibility that the ${ }^{14} \mathrm{C}$ concentration in atmospheric $\mathrm{CO}_{2}$ may vary spatially (McCormac et al. 1995; Manning et al. 2001, 2010; Imamura et al. 2007). The IntCal09 calibration data sets are based on ${ }^{14} \mathrm{C}$ data for rings from trees grown in North America and Europe, but do not include data for rings from trees grown in other areas such as Japan. To address this shortcoming, ${ }^{14} \mathrm{C}$ data from bored cores sampled at Lake Suigetsu, Fukui Prefecture, Japan, will be incorporated in the age range of 11.2-52.8 ka BP in the latest calibration data sets (Bronk Ramsey et al. 2012). The Japanese Archipelago is located on the eastern margin of the Asian continent in the middle to lower latitudes, and the ${ }^{14} \mathrm{C}$ concentration in atmospheric $\mathrm{CO}_{2}$ over Japan may be lower than that over inland areas and northern locations such as North America or Europe. This lower ${ }^{14} \mathrm{C}$ concentration results from $\mathrm{CO}_{2}$ release into the atmosphere from the nearby ocean surface, which has a lower ${ }^{14} \mathrm{C}$ concentration, or from air mass flow over the Pacific Ocean delivered by East Asian monsoons during the summer, when plants grow rapidly. Therefore, the ${ }^{14} \mathrm{C}$ concentration of atmo-

\footnotetext{
${ }^{1}$ Center for Chronological Research, Nagoya University, Furo-cho, Chikusa ward, Nagoya 464-8602, Japan.

${ }^{2}$ Corresponding author, Email: nakamura@nendai.nagoya-u.ac.jp.

${ }^{3}$ Solar-Terrestrial Environment Laboratory, Nagoya University, Furo-cho, Chikusa ward, Nagoya 464-8602, Japan.

${ }^{4}$ Graduate School of Environmental Studies, Nagoya University, Furo-cho, Chikusa ward, Nagoya 464-8602, Japan.
}

(C) 2013 by the Arizona Board of Regents on behalf of the University of Arizona

Proceedings of the 21st International Radiocarbon Conference edited by A J T Jull \& C Hatté

RADIOCARBON, Vol 55, Nr 2-3, 2013, p 763-770 


\section{T Nakamura et al.}

spheric $\mathrm{CO}_{2}$ over Japan was investigated by measuring the ${ }^{14} \mathrm{C}$ ages of annual rings from Japanese trees whose calendar ages ranged from $2000 \mathrm{yr}$ old to the present.

In this experiment, the ${ }^{14} \mathrm{C}$ concentration in tree rings was measured on an annual basis, as opposed to a multi-year basis, to be used for the analysis of solar activity with a resolution of $1 \mathrm{yr}$. Using the ${ }^{14} \mathrm{C}$ measurement results from Nagoya University, shortening of the duration of the Schwabe cycle has been revealed during periods of weaker solar activity. In addition, a large and rapid increase in ${ }^{14} \mathrm{C}$ concentration has been observed in tree rings grown in the timespan $\mathrm{AD} 774-775$. The details of this research have been described elsewhere (Miyahara et al. 2006; Miyake et al. 2012; Nagaya et al. 2012).

\section{EXPERIMENTAL}

To compare tree-ring ${ }^{14} \mathrm{C}$ data for Japanese trees with those of IntCal09, we have measured ${ }^{14} \mathrm{C}$ ages of annual rings from 3 Japanese cedar trees grown on the Japanese Archipelago (Figure 1 and Table 1). The first tree, named Murouji-sugi, with a total of 382 annual rings, was collected from the Murouji Temple in Nara Prefecture, central Japan $\left(34^{\circ} \mathrm{N}, 136^{\circ} \mathrm{E}\right)$. The second tree, named Yakushima-sugi, with 712 annual rings, was collected from Yaku-shima Island in Kagoshima Prefecture, southern Kyushu, Japan $\left(30.2^{\circ} \mathrm{N}, 130.3^{\circ} \mathrm{E}\right)$. The third and largest tree, named Yakusugi, with 1480 annual rings, was collected from the central part of Yaku-shima Island at an altiutude of around $1000 \mathrm{~m}\left(30.3^{\circ} \mathrm{N}, 130.5^{\circ} \mathrm{E}\right)$.

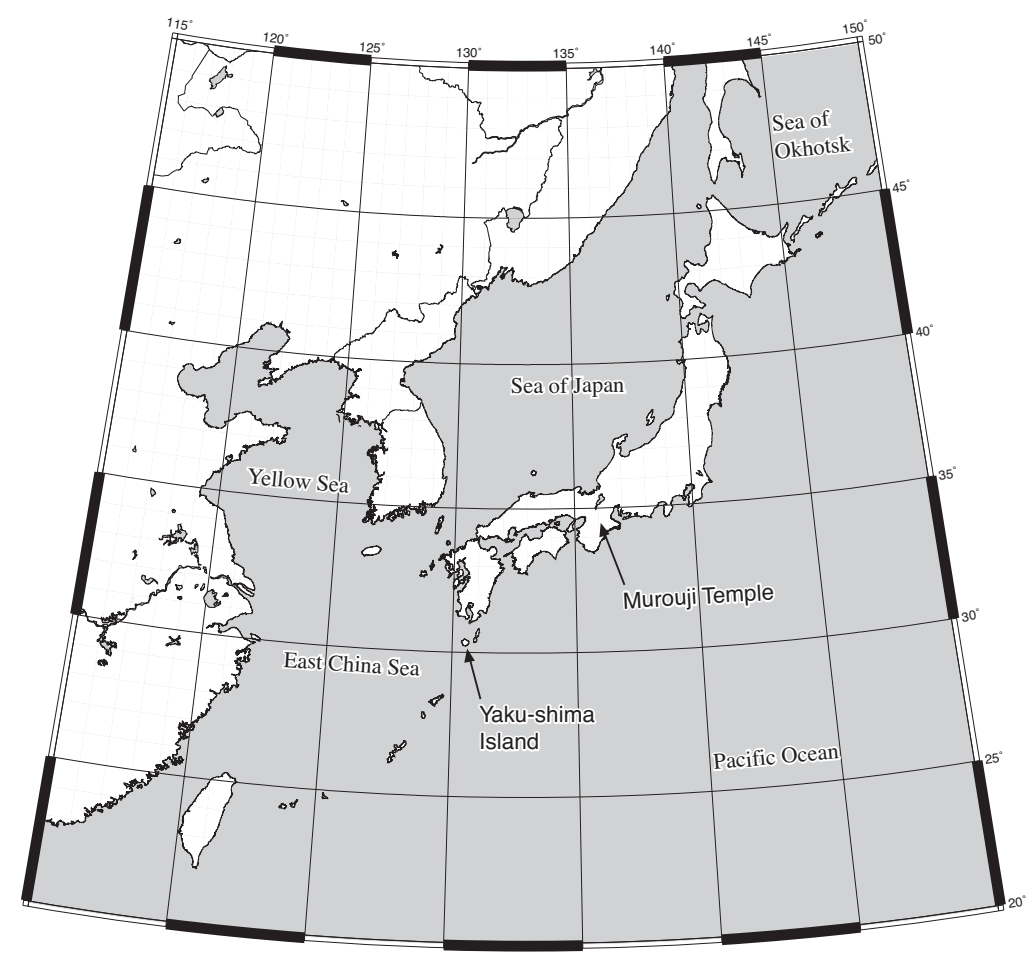

Figure 1 Collection locations of sample trees: Murouji-sugi tree from Nara Prefecture $\left(34^{\circ} \mathrm{N}, 136^{\circ} \mathrm{E}\right)$, Yakushima-sugi tree $\left(30.2^{\circ} \mathrm{N}, 130.3^{\circ} \mathrm{E}\right)$, and Yakusugi tree $\left(30.3^{\circ} \mathrm{N}\right.$, $\left.130.5^{\circ} \mathrm{E}\right)$ from Yaku-shima Island. 
${ }^{14}$ C Ages of Annual Rings from Japanese Wood

Table 1 List of tree rings analyzed.

\begin{tabular}{|c|c|c|c|}
\hline Tree name & Tree species & $\begin{array}{l}\text { Range of full } \\
\text { annual rings }\end{array}$ & $\begin{array}{l}\text { Age range of analyzed } \\
\text { annual rings (nr of ana- } \\
\text { lyzed rings) }\end{array}$ \\
\hline Murouji-sugi & $\begin{array}{l}\text { Japanese cedar, } \\
\text { Cryptomeria japonica }\end{array}$ & $\begin{array}{l}\text { AD } 1607-1998 \text {, } \\
\text { tot. } 392 \text { rings }\end{array}$ & $\begin{array}{l}\text { AD } 1790-1860(54) \\
\text { AD } 1617-1739(61)\end{array}$ \\
\hline Yakushima-sugi & $\begin{array}{l}\text { Japanese cedar, } \\
\text { C. japonica }\end{array}$ & $\begin{array}{l}\text { AD } 1280-1991 \text {, } \\
\text { tot. } 712 \text { rings }\end{array}$ & AD 1413-1615 (173) \\
\hline Yakusugi & $\begin{array}{l}\text { Yaku cedar, } \\
\text { C. japonica }\end{array}$ & $\begin{array}{l}\text { AD } 72-1551 \text {, } \\
\text { tot. } 1480 \text { rings }\end{array}$ & $\begin{array}{l}\text { AD 589-1072 (353) } \\
\text { AD 330-382(27) } \\
\text { AD 72-202(66) }\end{array}$ \\
\hline
\end{tabular}

Calendar ages of the annual rings of all 3 trees were determined by dendrochronology, by assessing the ring-width patterns by means of a $t$ value test against the respective master chronologies developed by Prof K Kimura and others (Miyake et al. 2012). For Murouji-sugi and Yakushima-sugi, the bomb peak values of ${ }^{14} \mathrm{C}$ concentration were also assessed in the annual rings to detect the calendar age of $\mathrm{AD} 1964$, the year when the bomb ${ }^{14} \mathrm{C}$ peak appeared in trees grown in the middle to northern latitudes of the Northern Hemisphere. The latter assignments were consistent with the former. We separated tree rings grown in AD 72-202, 330-382, 589-1072, 1413-1615, 1617-1739, and 17901860 , and have measured ${ }^{14} \mathrm{C}$ concentrations up to now for $66,27,353,173,61$, and 54 annual rings from the respective trees, on a single annual-ring basis (see Table 1 for details).

The individual annual rings were separated carefully from a core sample of the wood from an area of about $50 \times 50 \mathrm{~mm}^{2}$, and the alpha-cellulose fraction, which does not move between distinct annual rings, was extracted as follows: 1) samples were rinsed with ethanol followed with distilled water in an ultrasonic bath; 2) samples were treated successively with $1.2 \mathrm{M} \mathrm{HCl}, 1.2 \mathrm{M} \mathrm{NaOH}$, and again with $1.2 \mathrm{M} \mathrm{HCl}$ solutions at $80^{\circ} \mathrm{C}$ for several hours each (an acid-alkali-acid treatment); and 3) samples were bleached with hot $\mathrm{NaClO}_{2} / \mathrm{HCl}$ to remove lignin, and the resulting cellulose fraction was rinsed with boiling distilled water. The alpha-cellulose fraction thus separated was combusted to $\mathrm{CO}_{2}$, and the $\mathrm{CO}_{2}$ that evolved was purified with cold traps and graphitized with an iron catalyst by hydrogen reduction. The graphite targets were prepared at the Solar Terrestrial Laboratory, Nagoya University, and ${ }^{14} \mathrm{C} /{ }^{12} \mathrm{C}$ and ${ }^{13} \mathrm{C} /{ }^{12} \mathrm{C}$ ratios were measured at the Center for Chronological Research, Nagoya University (Nakamura et al. 2004, 2007).

We used the HOx-II standard (NIST new oxalic acid standard, SRM-4990C) as a reference for carbon isotope ratios and commercial oxalic acid containing no ${ }^{14} \mathrm{C}$ (oxalic acid dihydrates produced from Wako Pure Chemical Industries Ltd., Japan) for ${ }^{14} \mathrm{C}$ blank subtraction in the subsequent data analysis. Graphite targets were prepared from ancient wood $(\sim 90 \mathrm{ka} \mathrm{BP})$ and ${ }^{14} \mathrm{C}$ results compared with those of the commercial oxalic acid standard, and detected no clear differences. We also used the HOx-I standard (NIST old oxalic acid standard, SRM-4990) to check ${ }^{14} \mathrm{C}$ concentrations. In the same run of ${ }^{14} \mathrm{C}$ measurements, 6 NIST new standard, 3 NIST old standard, and 2 blank graphite targets were measured along with targets made from tree-ring samples. The standard deviation of ${ }^{14} \mathrm{C}$ concentration of the 6 NIST new standard targets was consistent with the statistical error calculated from ${ }^{14} \mathrm{C}$ counts on a single NIST new standard target. We repeated $3-5$ runs of ${ }^{14} \mathrm{C}$ measurements on a group of samples loaded at one time in the ion source. We calculated the ${ }^{14} \mathrm{C}$ concentration of the sample in each run, and an average value and an error were evaluated from the results of several runs. The concentration of ${ }^{14} \mathrm{C}$ was converted to conventional ${ }^{14} \mathrm{C}$ age, after correction of carbon isotopic fractionation using the $\delta^{13} \mathrm{C}$ value measured with AMS. The typical precision of the conventional ${ }^{14} \mathrm{C}$ age was $20-25 \mathrm{yr}$. 


\section{T Nakamura et al.}

\section{RESULTS AND DISCUSSION}

Figure 2 shows a comparison of ${ }^{14} \mathrm{C}$ ages obtained for individual annual rings of Japanese trees to those of the IntCal09 and SHCal04 data sets. Many of the ${ }^{14} \mathrm{C}$ ages measured for the Japanese tree rings are older than those estimated by IntCa109, but younger than those estimated by SHCal04 data sets. To clarify the ${ }^{14} \mathrm{C}$ age distribution for sample tree rings, ${ }^{14} \mathrm{C}$ ages for annual rings grown in the periods AD 72-382, 589-1072, 1413-1615, and 1617-1860 are shown separately in Figures 3a, 3b, $3 \mathrm{c}$, and $3 \mathrm{~d}$, respectively. It is clear that ${ }^{14} \mathrm{C}$ ages of annual rings from the Japanese tree samples tend to be distributed in a region older than those of the IntCal09 and younger than those of the SHCal04 data sets. The differences in ${ }^{14} \mathrm{C}$ ages of sample annual rings, as well as those of SHCal04 from IntCal09 data sets, are plotted against the calendar age in Figure 4.

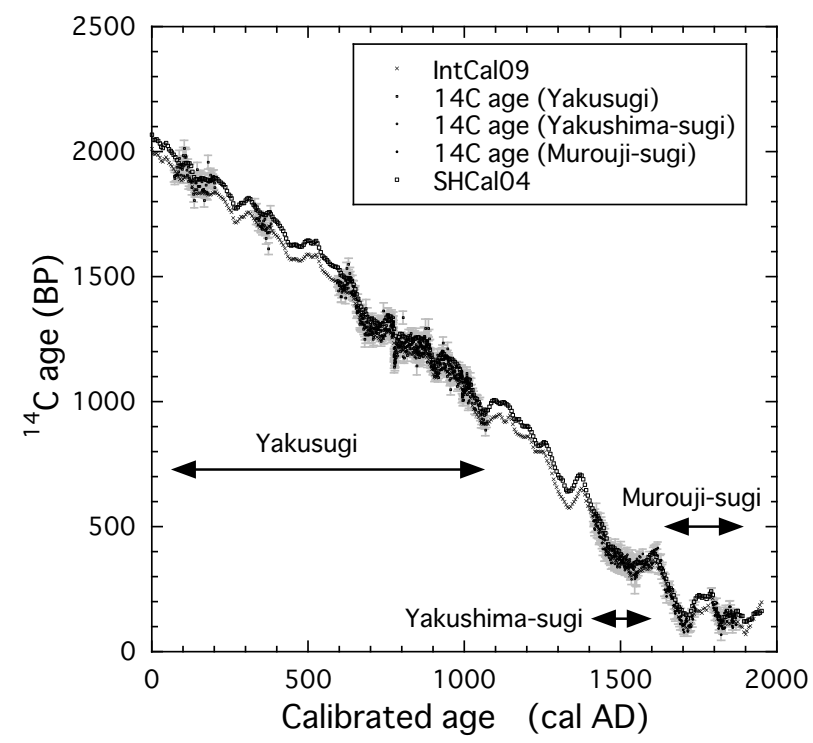

Figure 2 Comparison of ${ }^{14} \mathrm{C}$ ages among all tree-ring samples analyzed relative to IntCal09 and SHCal04 data sets.

When the measured ${ }^{14} \mathrm{C}$ dates are compared with data points in the IntCal09 and SHCal04 data sets, the ${ }^{14} \mathrm{C}$ wiggles observed in IntCal09 and SHCal04 data are also generally well represented in the Japanese tree data. In particular, the ${ }^{14} \mathrm{C}$ ages for Japanese wood in the calendar age range from $\mathrm{AD} 1617$ to 1860 are quite consistent with the IntCal09 data sets (Figure 3d). To investigate the degree of agreement between ${ }^{14} \mathrm{C}$ ages of Japanese trees and estimates from IntCal09 data sets, the differences between ${ }^{14} \mathrm{C}$ ages obtained at Nagoya from those of IntCal09 were evaluated. A linear interpolation was applied to IntCal09 data sets to evaluate annual ${ }^{14} \mathrm{C}$ age values, and an error propagation method was applied to calculate the errors associated with the ${ }^{14} \mathrm{C}$ age differences.

The average shifts of Nagoya ${ }^{14} \mathrm{C}$ ages from the IntCal09 ones and $1 \sigma$ errors were determined to be $+26 \pm 36,+24 \pm 30,+16 \pm 22,+5 \pm 21$, and $+14 \pm 22{ }^{14} \mathrm{C}$ yr, for the calendar-year intervals AD $72-$ $382,589-1072,1413-1615,1617-1739$, and 1790-1860, respectively (Table 2). The mean difference in ${ }^{14} \mathrm{C}$ age between SHCal04 and IntCal09 data is $+57 \pm 1{ }^{14} \mathrm{C}$ yr for the respective calendar dates from AD 1 to 960 . This mean difference is based on $\mathrm{SHCal04}{ }^{14} \mathrm{C}$ ages that are evaluated from 
${ }^{14}$ C Ages of Annual Rings from Japanese Wood
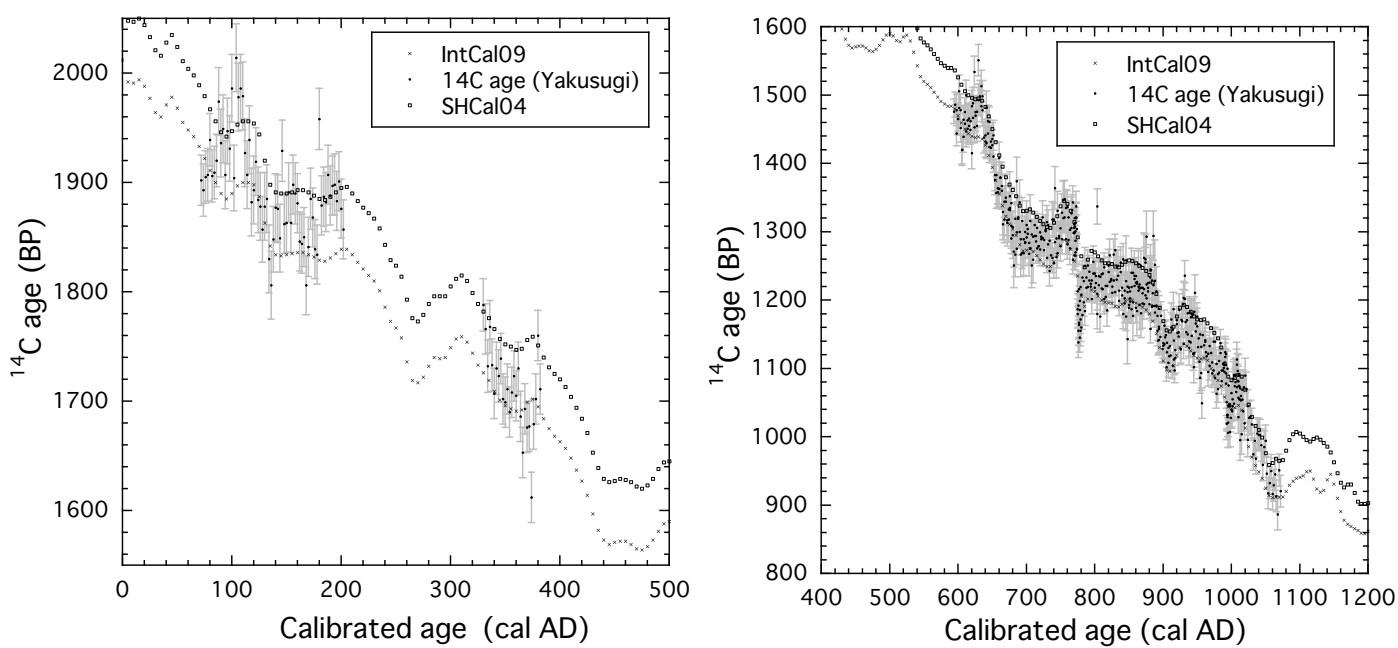

Figure 3a Comparison of ${ }^{14} \mathrm{C}$ ages among tree rings analyzed Figure $3 \mathrm{~b}$ Comparison between ${ }^{14} \mathrm{C}$ ages of tree rings analyzed (AD 72-382), and the IntCal09 and SHCal04 standard data (AD 589-1072), and the IntCal09 and SHCal04 standard data sets. sets.

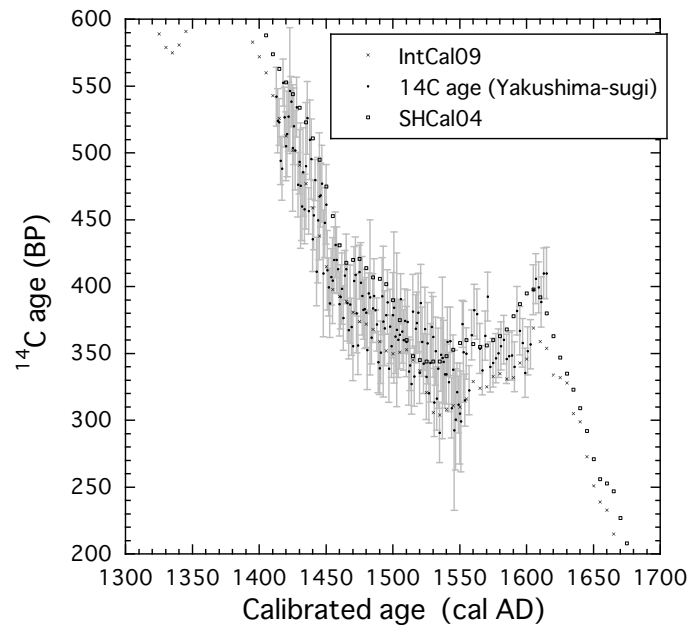

Figure $3 \mathrm{c}$ Comparison between ${ }^{14} \mathrm{C}$ ages of tree rings ana- Figure $3 \mathrm{~d}$ Comparison between ${ }^{14} \mathrm{C}$ ages of tree rings analyzed (AD 1413-1615), and the IntCal09 and SHCal04 stan- lyzed (AD 1617-1860), and the IntCal09 and SHCal04 standard data sets.

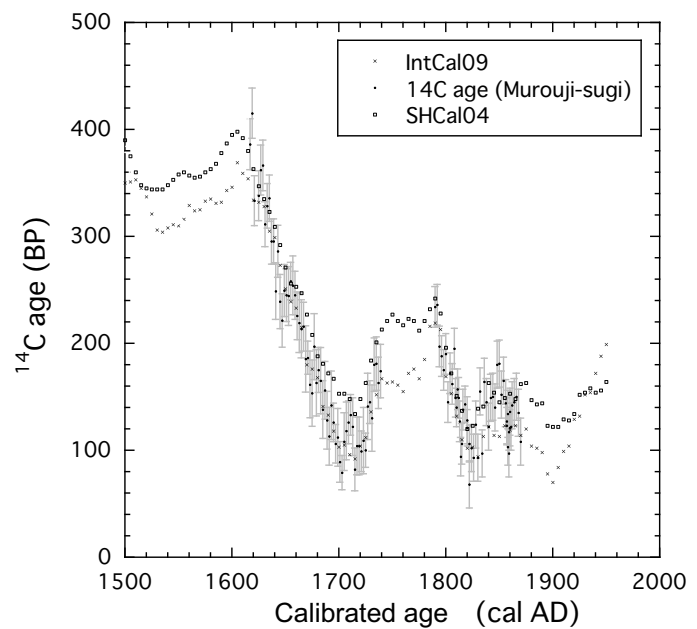

dard data sets.

IntCal09 ages according to the global box model of environmental carbon circulation, and on mean differences of $+54 \pm 7$ and $+36 \pm 14{ }^{14} \mathrm{C}$ yr for $\mathrm{AD} 960-1070$ and $1410-1860$, respectively, calculated for Southern Hemisphere tree-ring measurements. These results suggest that ${ }^{14} \mathrm{C}$ ages of the Yakusugi tree tend to be older than those estimated by IntCal09 and show values intermediate to those of IntCal09 and SHCal04 ${ }^{14} \mathrm{C}$ ages. A similar tendency has been reported for ${ }^{14} \mathrm{C}$ age values of other Japanese trees collected from Ashinoko Lake, central Japan, when compared with those of IntCa198, for the restricted calendar age range (AD 50-250) (Sakamoto et al. 2003), and also for several other ${ }^{14} \mathrm{C}$ measurements on Japanese trees (Imamura et al. 2007). In the present research, the ${ }^{14} \mathrm{C}$ age trends between Japanese trees and IntCal09 data are clear, and our data suggest that air 


\section{T Nakamura et al.}

masses containing $\mathrm{CO}_{2}$ with a lower ${ }^{14} \mathrm{C}$ concentration that occasionally arrive in southern Japan from the Southern Hemisphere may be responsible for this discrepancy.

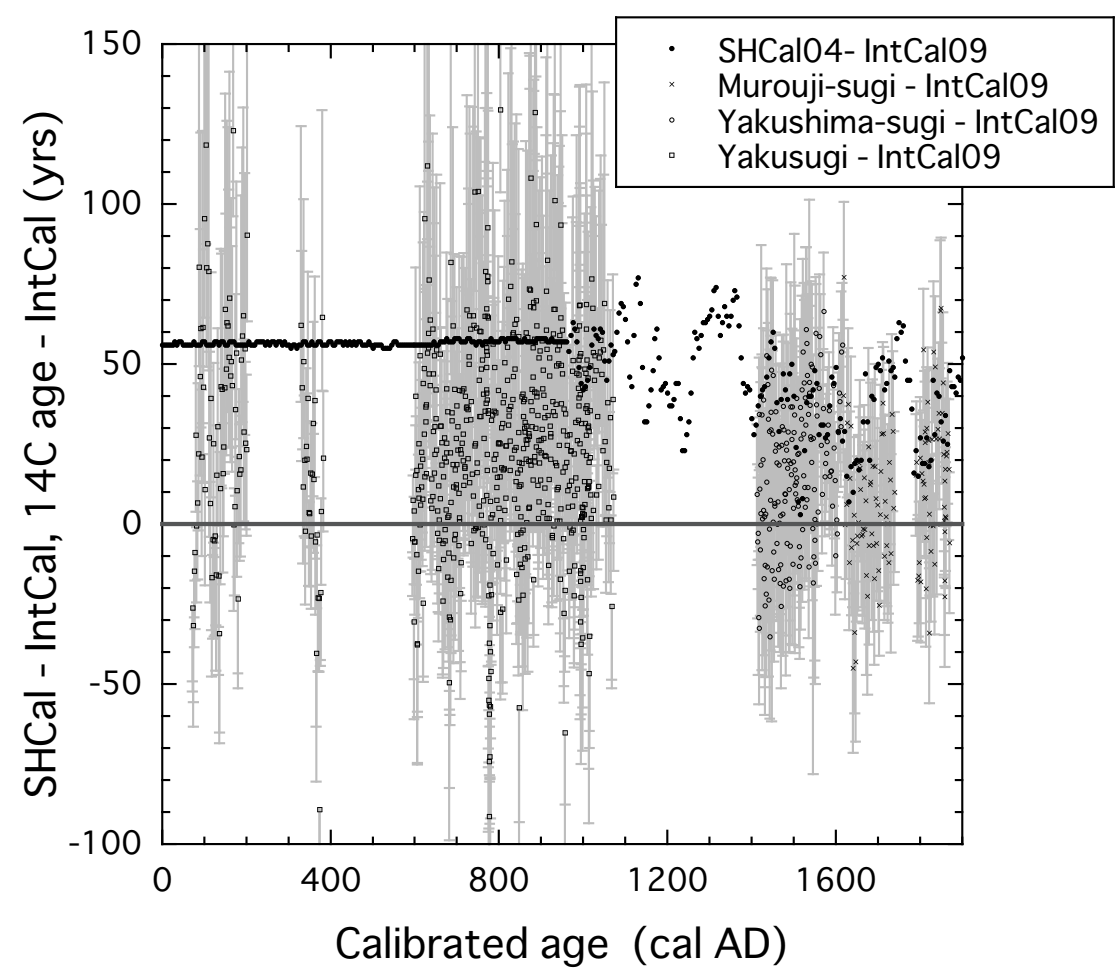

Figure 4 Differences between ${ }^{14} \mathrm{C}$ ages of all tree-ring samples and SHCal04 compared with IntCal09

Table 2 Differences in the ${ }^{14} \mathrm{C}$ ages of Japanese tree rings and SHCal04 compared with IntCal09.

\begin{tabular}{lll}
\hline Tree name & $\begin{array}{l}\text { Range of } \\
\text { annual rings }\end{array}$ & $\begin{array}{l}{ }^{14} \mathrm{C} \text { age difference }\left({ }^{14} \mathrm{C} \text { yr }\right) \\
(\text { Japanese ring/SHCal04 }- \text { IntCal09) }\end{array}$ \\
\hline Murouji-sugi & AD 1790-1860 & $14 \pm 22$ \\
& AD 1617-1739 & $5 \pm 21$ \\
Yakushima-sugi & AD 1413-1615 & $16 \pm 22$ \\
Yakusugi & AD 589-1072 & $24 \pm 30$ \\
Yakusugi & AD 72-382 & $26 \pm 36$ \\
SHCal04 & AD 1410-1860 & $36 \pm 14$ \\
& AD 960-1070 & $54 \pm 7$ \\
& AD 1-960 & $57 \pm 1$ \\
\hline
\end{tabular}

Regarding the mechanism by which southern atmospheric air is supplied to the lower latitudes of the Northern Hemisphere, Hua and Barbetti $(2007,2012)$ pointed out that the Intertropical Convergence Zone (ITCZ) moves into the Northern Hemisphere as far north as $30^{\circ}$ due to the East Asian monsoon during summer, transferring air masses with lower ${ }^{14} \mathrm{C}$ concentration (typically equivalent to a ${ }^{14} \mathrm{C}$ age excess of $20-50 \mathrm{yr}$ ) from the southern atmosphere to the Northern Hemisphere. The ITCZ boundary may move more northwards in years when the Pacific high pressure strengthens due to 
higher solar activity (Figure 5). As summarized in Figure 5, during periods of high solar activity, the ${ }^{14} \mathrm{C}$ production rate on the Earth's surface decreases and ${ }^{14} \mathrm{C}$ concentration in atmospheric $\mathrm{CO}_{2}$ decreases, which results in older estimates of ${ }^{14} \mathrm{C}$ ages for terrestrial samples grown during those periods. In addition, Pacific barometric pressure increases due to higher solar activity, and air masses with lower ${ }^{14} \mathrm{C}$ concentration in the Pacific region are supplied preferentially to the Japanese Archipelago by East Asian monsoons during the summer.
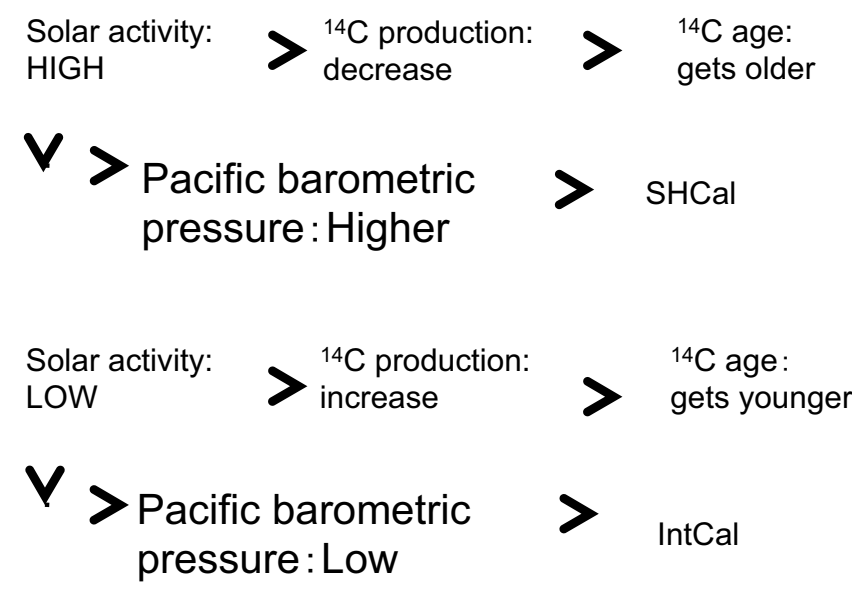

Figure 5 Degree of solar activity relative to suitability of sample ${ }^{14} \mathrm{C}$ age calibration using the IntCal or SHCal standards.

When solar activity is weak, on the other hand, the production rate of ${ }^{14} \mathrm{C}$ increases, and the ${ }^{14} \mathrm{C}$ age of terrestrial samples appears to be younger. Pacific barometric pressure is not activated by weak solar activity, and the Japanese Archipelago is dominated by the air masses originating from the Northern Hemisphere. During periods of weak solar activity, IntCal depicts the relationships between ${ }^{14} \mathrm{C}$ ages and calendar ages well. Therefore, the ${ }^{14} \mathrm{C}$ ages of trees grown in the southern Japanese Archipelago fluctuate between those defined by IntCal and SHCal standard boundaries (Figures 2-4), according to the strength of solar activity.

Japan is situated near the border of the ITCZ during summer, and the ${ }^{14} \mathrm{C}$ concentration of atmospheric $\mathrm{CO}_{2}$ over Japan can be influenced by air masses from the Southern Hemisphere, which have lower ${ }^{14} \mathrm{C}$ concentrations during periods of higher solar activity and strengthened East Asian summer monsoons. Our results suggest that the Japanese Archipelago is located in a critical zone in which it is difficult to calibrate the ${ }^{14} \mathrm{C}$ ages of local tree-ring samples with existing calibration data sets. Most importantly, calibration of ${ }^{14} \mathrm{C}$ dates of Japanese samples with IntCal09 may result in a systematic upward shift in calibrated calendar ages by about $30 \mathrm{yr}$ relative to the sample optimum calendar ages.

\section{CONCLUSION}

We measured the ${ }^{14} \mathrm{C}$ age of annual rings from 3 Japanese trees with calendar dates ranging from $\sim 2000 \mathrm{yr}$ old to present, and we compared the tree-ring ${ }^{14} \mathrm{C}$ age with the corresponding ${ }^{14} \mathrm{C}$ age in IntCal09. It was revealed that the ${ }^{14} \mathrm{C}$ ages of the annual rings of Japanese trees are not consistent with IntCal09 data sets in some instances. Often, the ${ }^{14} \mathrm{C}$ ages of tree rings are older than those of IntCa109, but younger than those of SHCal04. The shift in Nagoya ${ }^{14} \mathrm{C}$ age from IntCal09 data sets may depend on the origin of the samples on the Japanese Archipelago, as well as the level of solar 


\section{T Nakamura et al.}

activity (insolation and solar magnetic field) during the period when the samples were growing. We tested 2 kinds of samples: one grown in Nara Prefecture in central Japan, and the other grown on Yaku-shima Island, at the southern end of the Japanese Archipelago. The profile of carbon taken up by the trees that grew on Yaku-shima Island, closer to the ITCZ during summer, is likely to have been influenced more by the low- ${ }^{14} \mathrm{C}$-concentration air masses from the Southern Hemisphere.

\section{ACKNOWLEDGMENTS}

The authors thank Prof K Kimura of Fukushima University for dendrochronological dating of the sample tree rings, and Dr Q Hua of ANSTO, Australia, for valuable discussions on the analysis of ${ }^{14} \mathrm{C}$ ages of Japanese trees. We would also like to thank the staff of the Technical Center of Nagoya University for their kind support in maintaining the HVEE Tandetron ${ }^{14} \mathrm{C}$ AMS system. This work was supported partly by the Grant-in-Aid for Scientific Research of the Japan Society for the Promotion of Science (JSPS) (Subject Nos. 15202023, 16320108, 22340144, and 22240082).

\section{REFERENCES}

Bronk Ramsey C, Staff RA, Bryant CL, Brock F, Kitagawa $\mathrm{H}$, van der Plicht J, Schlolaut G, Marshall MH, Brauer A, Lamb HF, Payne RL, Tarasov PE, Haraguchi T, Gotanda K, Yonenobu H, Yokoyama Y, Tada R, Nakagawa T. 2012. A complete terrestrial radiocarbon record for 11.2 to $52.8 \mathrm{kyr}$ B.P. Science $338(6105)$ : $370-4$.

Hua Q, Barbetti M. 2007. Influence of atmospheric circulation on regional ${ }^{14} \mathrm{CO}_{2}$ differences. Journal of Geophysical Research 112: D19102, doi:10.1029/ 2006JD007898.

Hua Q, Barbetti M. 2012. Monsoonal influence on Southern Hemisphere ${ }^{14} \mathrm{CO}_{2}$. Geophysical Research Letters 39, L19806, doi:10.1029/2012GL052971.

Imamura M, Ozaki H, Mitsutani T, Niu E, Itoh S. 2007. Radiocarbon wiggle-matching of Japanese historical materials with a possible systematic age offset. Radiocarbon 49(2):331-7.

Manning SW, Kromer B, Kuniholum I, Newton MW. 2001. Anatolian tree rings and a new chronology for the East Mediterranean Bronze-Iron Ages. Science 294(5551):2532-5.

Manning SW, Kromer B, Bronk Ramsey C, Pearson CL, Talamo S, Trano N, Watkins JD. 2010. ${ }^{14} \mathrm{C}$ record and wiggle-match placement for the Anatolian (Gordion area) juniper tree-ring chronology $\sim 1729$ to $750 \mathrm{cal}$ $\mathrm{BC}$, and typical Aegean/Anatolian (growing season related) regional ${ }^{14} \mathrm{C}$ offset assessment. Radiocarbon 52(4):1571-97.

McCormac FG, Baillie MGL, Pilcher JR. 1995. Location-dependent differences in the ${ }^{14} \mathrm{C}$ content of wood. Radiocarbon 37(2):395-407.

McCormac FG, Hogg AG, Blackwell PG, Buck CE, Higham TFG, Reimer PJ. 2004. SHCal southern hemisphere calibration, 0-11.0 cal kyr BP. Radiocarbon 46(3):1087-92.

Miyahara H, Masuda K, Muraki Y, Kitagawa H, Naka- mura T. 2006. Variation of solar cyclicity during the Spoerer Minimum. Journal of Geophysical Research 111: A03103, doi:10.1029/2005JA011016.

Miyake F, Nagaya K, Masuda K, Nakamura T. 2012. A signature of cosmic ray increase in $\mathrm{AD} 774-775$ from tree rings in Japan. Nature 486(7402)240-2.

Nagaya K, Kitazawa K, Miyake F, Masuda K, Muraki Y, Nakamura T, Miyahara H, Matsuzaki H. 2012. Variation of the Scwabe cycle length during the grand solar minimum in the 4th century $\mathrm{BC}$ deduced from radiocarbon content in tree rings. Solar Physics 280(1): 223-36.

Nakamura T, Niu E, Oda H, Ikeda A, Minami M, Ohta T, Oda T. 2004. High precision ${ }^{14} \mathrm{C}$ measurements with the HVEE Tandetron AMS system at Nagoya University. Nuclear Instruments and Methods in Physics Research B 223-224:124-9.

Nakamura T, Miyahara H, Masuda K, Menjo H, Kuwana K, Kimura K, Okuno M, Minami M, Oda H, Rakowski A, Ohta T, Ikeda A, Niu E. 2007. High precision ${ }^{14} \mathrm{C}$ measurements and wiggle-match dating of tree rings at Nagoya University. Nuclear Instruments and Methods in Physics Research B 259(1):408-13.

Reimer PJ, Baillie MGL, Bard E, Bayliss A, Beck JW, Blackwell PG, Bronk Ramsey C, Buck CE, Burr GS, Edwards RL, Friedrich M, Grootes PM, Guilderson TP, Hajdas I, Heaton T, Hogg AG, Hughen KA, Kaiser KF, Kromer B, McCormac FG, Manning SW, Reimer RW, Richards DA, Southon JR, Talamo S, Turney CSM, van der Plicht J, Weyhenmeyer CE. 2009. IntCal09 and Marine09 radiocarbon age calibration curves, 0-50,000 years cal BP. Radiocarbon 51(4): 1111-50.

Sakamoto M, Imamura M, van der Plicht J, Mitsutani T, Sahara M. 2003. Radiocarbon calibration for Japanese wood samples. Radiocarbon 45(1):81-9. 